\title{
THE IMPACT OF COMPLEMENTARY MEDICINE ON \\ SUSTAINABLE TOURISM DEVELOPMENT THROUGH EVENT AND \\ NATURE-BASED TOURISM
}

\author{
Vesna Krstićl, Marijana Đurađevićn ${ }^{2}$ Igor Trišić3 \\ *Corresponding authorE-mail:vesnak16@hotmail.com
}

A R T I C L E I N F O
Original Article
Received: 02 February 2020
Accepted: 25 April 2020
doi:10.5937/ekoPolj2002377K
UDC 61:[502.131.1:338.48

Keywords:

complementary medicine, sustainable tourism, event, nature-based tourism

JEL: I15, Z32, Q57

\begin{abstract}
A B S T R A C T
The subject of this research is to look at the attitudes of spa tourists towards complementary medicine and the possibilities of its application within spa services. The aim of the research is to identify certain scientific results that can contribute to the creation of an adequate tourism product. In the research, a prospective study is used and it was done by applying a standardized questionnaire. Testing the correlation of the answers given was examined and shown by the Analysis The Pearson Correlation method. The obtained results confirmed the hypotheses: complementary medicine is a significant component of the sustainable development of health tourism in spa destinations in Serbia, and that the organization of an adequate complementary medicine tourism event can increase tourists' motivation for visits and their significant relation to nature-based tourism, which would significantly affect on sustainable tourism development of spa tourism. The intensification of the growth of awareness among the respondents about the importance of complementary medicine in tourism planning and development is evident, and by providing socio-cultural, economic and environmental benefits, the basic postulates of sustainable tourism development are directly fulfilled.
\end{abstract}

(C) 2020 EA. All rights reserved.

1 Vesna Krstić, PhD candidate, University of Kragujevac, Faculty of Hotel Management and Tourism, Vojvođanska №5a, 36210 Vrnjačka Banja; Republic of Serbia, Phone: +38162552893, E-mail: vesnak16@hotmail.com, ORCID ID (https://orcid.org/0000-0003-2541-5440)

2 Marijana Djuradjević, PhD candidate, University of Kragujevac, Faculty of Hotel Management and Tourism, Vojvođanska №5a, 36210 Vrnjačka Banja; Republic of Serbia, Phone: +38166334872, E-mail: mdjuradjevic@gmail.com, ORCID ID (https://orcid. org/0000-0001-9989-7900)

3 Igor Trišić, PhD candidate, University of Kragujevac, Faculty of Hotel Management and Tourism, Vojvođanska №5a, 36210 Vrnjačka Banja; Republic of Serbia, Phone: +381641431375, E-mail: trisici@hotmail.com, ORCID ID (https://orcid.org/0000-0002-6497-9276) 


\section{Introduction}

Health tourism, as one of the most widespread types of travel, is influenced by many factors (Tucki \& Hadzik, 2013). Some of these are new products and technologies in contemporary rehabilitation and prevention treatments that can be implemented within the health tourism destination (Hadzik, 2009). The use of medicinal herbs for health purposes is a significant form of complementary medicine dating back to the early stages of human development. In addition to nature-based tourism, complementary medicine can be promoted through various ethno-social events (Yoo, Lee \& Lee, 2015; Wisnom \& Gallagher, 2018). Nature-based tourism makes a significant link in health tourism, because the ways of access to medicinal plant raw materials and the relation to nature sometimes represent the traditions of a particular people and a model for the realization of tourism needs in nature (Wardle et al., 2018).

Within the global health tourism, wellness tourism has specific opportunities for growth (Global Wellness Institute, 2015). Medical and health tourism are forms of tourism that comprise the therapeutic and wellness segment (Smith \& Puczkó, 2015; Pan et al., 2019), linked to the movement of tourists on their own initiative (Connell, 2013) to special resorts that have all the necessary resources (Suess, Baloglu \& Busser, 2018). The main motive of these trips is, at the same time, any form of health promotion combined with recreation and entertainment (Vetitnev \& Kuskov, 2010). Wellness tourism (as an example of innovation) has the largest share in medical tourism, and is characterized by the largest increase in value in recent years (Euromonitor International, 2012). These motives to go to spas influence the choice of leisure activities and forms, and are an inspiration for creating a new concept of health tourism products, meeting the needs of tourists (Dryglas, 2009). On the other hand, they are constantly increasing competition, changing markets and technologies, forcing companies and health resorts to implement innovations, especially product innovations. A new approach to life that includes health, based on the "wellness" paradigm, results in visible changes in health tourism in spas (Kim et al., 2019). It is focused on "extending life while maintaining health, physical and mental abilities, youthful appearance, well-being and social activity" (Sallmann, 2010).

Different events represent a significant model for promoting this form of tourism. Whether it is local herbal fairs and its application in wellness and spa tourism, or are events of an international nature, health and nature-based forms of tourism can initiate various tourism activities (Whittle, Stewart \& Fisher, 2015; Doran, Hanss \& Larsen, 2017). The common link between these forms of tourism is nature, and the right attitude of man towards it. Properly integrated into the tourism offer, health, events and nature-based forms of tourism can contribute to significant tourism revenue. With proper planning and development, these forms of tourism can contribute to increasing socio-cultural, economic (Cvijanović, Pantić \& Ignjatijević, 2020) and environmental benefits in tourist destinations (Kostić, Ratković \& Forlani, 2019).

Achieving these positive results is also the basic postulate of sustainable tourism development (Trisić, Štetić \& Krstić, 2018). Innovations in spa health tourism primarily 
relate to offers connected to health services. Innovations in spa health tourism are recognized in dimensions as: functional (as they relate to others), useful (as value carrier - patient benefit), technical (as a process in the process of diagnosis and therapy), and relational (as a specific recipient-donor dialogue) service) (Sawicki, 2014). Innovations play a key role in tourism (Aldebert et al., 2011), one of the essential elements of consumer satisfaction with the tourism service that enables the producer to differentiate himself from the competition (Živković, 2009). The modern tourist, a man of today, in order to recover, rest, recover energy, rejuvenate, or heal, visits spa complexes relatively frequently (Manić, 2018). His motives can be classified as "rejuvenation", "socialization", "hedonism", "obsession with health and beauty", "relaxation" and "escape from routine". Tourism offers products and services designed to improve the quality of life (Dimitrovski \& Todorović, 2015). Event tourism allows tourists to relax, enhance relatives or other social relationships, experience something unusual and have fun (Senić \& Senić, 2016). Visitors can attend the event either for substantially primary reasons, that is, their primary reason for visiting the destination, or for incidental reasons (Getz \& Page, 2016). Event management goes through a number of stages: initiation, planning, implementation, event and closure (Event Management Body of Knowledge, 1999). With changes in consumer preferences in the tourism market towards adherence to sustainability criteria, the process of adapting tourism destinations in terms of competitive advantage and sustainable development will last (Popesku, 2011), which entails three pillars of sustainability: economic, socio-cultural and environmental (Vujović, Cvijanović, \& Štetić, 2012; Golob et al., 2015). Events are crucial in promoting the destination and attracting visitors who will spend their money in the destination (Getz \& Page, 2016) and contribute to the huge profits of the destination (Giampiccoli et al., 2015). Event tourism plays an important role in the modern economy and can have a significant impact, where sustainability-oriented tourism has become an important component of tourism destination development and planning (Golob et al., 2015; Vujović, Curčić, \& Miletić, 2016; Cvijanović, Simić \& Vukotić, 2018).

The subject of this research is to look at the attitudes of spa tourists towards complementary medicine and the possibilities of its application within spa services. The hypotheses of the research are: complementary medicine is a significant component of the sustainable development of health tourism in spa destinations in Serbia $\left(\mathrm{H}_{1}\right)$ and the organization of an adequate complementary medicine tourism event would increase tourists' motivation for visits and their significant relation to nature-based tourism (through traditional plant picking and nature stay), which would have a significant impact on the sustainable tourism development of spa tourism $\left(\mathrm{H}_{2}\right)$.

The aim of the research in this paper is to identify certain scientific results that can contribute to the creation of an adequate tourism product. This significant tourism product would integrate complementary medicine with events and nature-based forms of tourism into a single unity, thus meeting the expressed needs of spa tourists. In addition to directly meeting the need to improve and upgrade their health status, tourists also expressed interest in learning about the available herbal medicinal resources of Vrnjačka Banja and its natural environment. Organizing an adequate tourism event in 
the field of complementary medicine would increase tourists' motivation to visit, which would significantly influence the sustainable development of spa tourism.

The expected results of the research are that complementary medicine is a significant component of health tourism, and that in addition to nature-based tourism and events, it can contribute to the sustainable tourism development of Serbia.

\section{Materials and methods}

A prospective study was conducted using a questionnaire containing four groups of variables: demographic characteristics, knowledge of properties and use of medicinal herbs, initiation of treatment, and respondents' attitudes toward phytotherapy and complementary (traditional) medicine. Within this paper, three groups of variables are presented: demographic characteristics, treatment initiation, and respondents' attitudes toward phytotherapy and complementary medicine. The research instrument is a standardized questionnaire, prepared according to WHO guidelines for assessing the availability, use, coordination and comprehensiveness of health care used in the WHO survey in the Republic of Serbia in 2009, which is thematically tailored to the research needs. The survey of 62 Vrnjačka Banja tourists was conducted in the period July - September 2019. Respondents were selected by random selection method and completed questionnaires in the presence of interviewers. Respondents were asked a total of 15 questions, of which 13 questions were used for research and analysis. The questions were assigned numbers $\mathrm{n}_{1}, \mathrm{n}_{2}, \mathrm{n}_{3}, \mathrm{n}_{4}, \mathrm{n}_{5}, \mathrm{n}_{6}, \mathrm{n}_{7} \ldots \mathrm{n}_{13}$. The questionnaire was prepared using a structured interview method, composed of two parts. In the first part, consisting of questions 1 and 2, the respondents presented their answers by writing the answer that is related to a certain offered number $(1,2,3$ or 4$)$, depending on its meaning and truthfulness. In the second part of the questionnaire, from the third question, three-level Likert scale answers were given: Yes - I agree (number 1 offered); Partially agree (2) and Disagree (3). The Likert scale allows respondents to adequately express their level of agreement with certain statements in the questionnaire (Joshi et al., 2015). The data were described by descriptive statistical methods and analyzed by appropriate statistical-analytical method using SPSS (Statistical Package for the Social Sciences) software. Testing the correlation of the answers given was examined and shown by the Analysis The Pearson Correlation method, to determine whether the model of differences obtained was relevant to the analysis of the results. The number of 62 randomly selected respondents represents a small but significant sample for analyzing the current state of the spa and event tourism market in Vrnjačka Banja, which is a significant tourist destination in the Republic of Serbia and in the region. Analyzing the answers from the questionnaire can contribute to the construction of scientific conclusions regarding sustainable tourism development, ie whether events, spa and nature-based tourism can be significant for sustainable tourism development. The results may also point to further research related to these areas of tourism planning and development. 


\section{Results and Discussions}

The sample consisted of 62 respondents, $59.7 \%$ female and $40.3 \%$ male. The observed difference in gender distribution is not at the level of statistical significance. The average age of the respondents was $55.48 \pm 15.18$ years, with the average age of the female being 8 years. Half of the respondents have a high school diploma and a third have a college/faculty diploma. Every tenth respondent evaluates his financial status as very good. Of the total number of respondents, $43.5 \%$ live in the city, $32.3 \%$ in the suburbs and $24.2 \%$ in the village. The largest number of respondents came from Central Serbia, $43.5 \%$, and the smallest from Eastern Serbia, $11.3 \%$. The analysis by gender shows that there is no statistically significant difference in the level of education, the assessment of the material situation, the part of Serbia where the respondents come from and the places of residence between the male and female persons. The structure of the respondents can be summarized in Table 1 .

Table 1. Structure of respondents

\begin{tabular}{|c|c|c|c|c|c|}
\hline \multicolumn{2}{|c|}{ Gender } & Frequency & Percent & Mean & Std. dev. \\
\hline \multicolumn{2}{|l|}{ Male } & 25 & 40.3 & \multirow{3}{*}{1.4} & \multirow{3}{*}{.495} \\
\hline \multicolumn{2}{|l|}{ Female } & 37 & 59.7 & & \\
\hline \multicolumn{2}{|l|}{ Total } & 62 & 100 & & \\
\hline \multicolumn{2}{|c|}{ Education } & frequency & Percent & Mean & Std. dev. \\
\hline \multicolumn{2}{|c|}{ Unfinished school } & 2 & 3.2 & \multirow{5}{*}{3.15} & \multirow{5}{*}{.721} \\
\hline \multicolumn{2}{|c|}{ primary education } & 6 & 9.7 & & \\
\hline \multicolumn{2}{|c|}{ secondary education } & 35 & 56.5 & & \\
\hline \multicolumn{2}{|c|}{ Tertiary and faculty education } & 19 & 30.6 & & \\
\hline \multicolumn{2}{|c|}{ Total } & 62 & 100 & & \\
\hline \multirow{2}{*}{ age structure } & $\mathrm{N}$ & Min & Max & Mean & Std. dev. \\
\hline & 62 & 18 & 82 & 55.48 & 15.178 \\
\hline \multicolumn{2}{|c|}{$\begin{array}{l}\text { The environment you come } \\
\text { from }\end{array}$} & frequency & Percent & mean & Std. dev. \\
\hline \multicolumn{2}{|c|}{ City } & 27 & 43.5 & \multirow{4}{*}{1.81} & \multirow{4}{*}{.807} \\
\hline \multicolumn{2}{|l|}{ Suburb } & 20 & 32.3 & & \\
\hline \multicolumn{2}{|c|}{ Rural environment } & 15 & 24.2 & & \\
\hline \multicolumn{2}{|l|}{ Total } & 62 & 100 & & \\
\hline \multicolumn{2}{|c|}{ The region you come from } & Frequency & Percent & Mean & Std. dev. \\
\hline \multicolumn{2}{|c|}{ Vojvodina } & 9 & 14.5 & \multirow{6}{*}{2.90} & \multirow{6}{*}{1.183} \\
\hline \multicolumn{2}{|c|}{ Western Serbia Srbija } & 11 & 17.7 & & \\
\hline \multicolumn{2}{|c|}{ Central Srbija } & 27 & 43.5 & & \\
\hline \multicolumn{2}{|c|}{ Eastern Srbija } & 7 & 11.3 & & \\
\hline \multicolumn{2}{|c|}{ Foreign country } & 8 & 12.9 & & \\
\hline \multicolumn{2}{|c|}{ Total } & 62 & 100 & & \\
\hline
\end{tabular}

Source: Author research

The level of education has an impact on how treatment is started, so that people with secondary education, as well as those with tertiary /faculty education, most often start treatment with the use of medicinal herbs. Respondents who evaluate their financial 
status as good most often start treatment with medicinal plants, while those with mediocre financial status most often visit a doctor first.

Persons coming from Vojvodina usually start treatment with medicinal herbs, while respondents from Western, Central, Eastern and Southern Serbia first consult a doctor.

To the question $n_{1}$ - Do you use herbs, and $n_{2}$ - Do the family members of the respondents use herbs, the respondents gave their answers in the following relation (Table 2).

Table 2. Respondents' answers to questions $\mathrm{n}_{1}$ and $\mathrm{n}_{2}$

\begin{tabular}{|l|c|c|c|c|}
\hline \multicolumn{1}{|c|}{ Questions } & \multicolumn{2}{c|}{$\mathbf{n}_{1}$} & \multicolumn{2}{c|}{$\mathbf{n}_{2}$} \\
\hline \multicolumn{1}{|c|}{ Valid } & Frequency & Percent & Frequency & Percent \\
\hline Daily & 14 & 22.6 & 6 & 9.7 \\
\hline Occasionally, when I'm healthy & 27 & 43.5 & 29 & 46.8 \\
\hline Only in case of illness & 21 & 33.9 & 27 & 43.5 \\
\hline Total & 62 & 100 & 62 & 100 \\
\hline$t$ & \multicolumn{2}{|c|}{22.216} & \multicolumn{2}{c|}{28.268} \\
\hline Sig. (2-tailed) & \multicolumn{2}{|c|}{.000} & \multicolumn{2}{c|}{600} \\
\hline df & \multicolumn{2}{|c|}{2.113} & \multicolumn{2}{c|}{2.339} \\
\hline Mean Difference & \multicolumn{2}{|c|}{.095} & \multicolumn{2}{c|}{} \\
\hline Std. Error Mean & \multicolumn{2}{|c|}{} \\
\hline
\end{tabular}

Source: Author research

Analyzing the answers, presented in Table 2, it is concluded that the majority of respondents use herbs occasionally, or when their current health needs to be improved. Likewise, the respondent's family, in the largest number of responses, occasionally uses herbs or, when ill. It is concluded that the respondents are competent to provide answers regarding the role of complementary medicine in sustainable tourism development through events, nature-based and spa forms of tourism, since they make significant use of medicinal herbs.

The second part of the questionnaire deals with the respondents' agreement with the offered options (they agree completely, partially agree, or disagree). The structure of questions 3 through 13 from the questionnaire is shown in Table 3.

Table 3. Question structure of the second part of the questionnaire

\begin{tabular}{|l|l|}
\hline \multicolumn{2}{|c|}{ Questions } \\
\hline$n_{3}$ & Serbia is rich in medicinal plants that grow freely in nature \\
\hline$n_{4}$ & $\begin{array}{l}\text { Vrnjačka Banja is rich in medicinal plants important for the development of events and nature- } \\
\text { based forms of tourism }\end{array}$ \\
\hline$n_{5}$ & Medicinal plants are good for health \\
\hline$n_{6}$ & Medicinal plants should be harvested for their function and tradition \\
\hline$n_{7}$ & I would love to collect herbs while staying at the spa \\
\hline$n_{8}$ & In many countries, traditional medicines are used in medical treatment besides medical \\
\hline$n_{9}$ & $\begin{array}{l}\text { In many countries, physicians and experts in traditional (complementary) medicine also } \\
\text { participate in treatment }\end{array}$ \\
\hline
\end{tabular}




\begin{tabular}{|l|l|}
\hline \multicolumn{2}{|c|}{ Questions } \\
\hline$n_{10}$ & $\begin{array}{l}\text { I think that the same treatment principles should be applied to us through the spa form of } \\
\text { tourism as a significant tourist offer }\end{array}$ \\
\hline$n_{11}$ & If the same treatment principles were applied in the spa, the treatment would be more effective \\
\hline$n_{12}$ & $\begin{array}{l}\text { If traditional (complementary) medicine were part of spa tourism, as the initiator of events and } \\
\text { nature based forms of tourism, I would visit the spa more often }\end{array}$ \\
\hline$n_{13}$ & If the same treatment principles were applied in the spa, more tourists would be staying in the spa \\
\hline
\end{tabular}

Source: Author research

Respondents' answers to the questions asked can be presented and analyzed structurally in Table 4.

Table 4. Respondents' answers to the second group of questions

\begin{tabular}{|c|c|c|c|c|c|c|c|c|}
\hline \multicolumn{9}{|c|}{ Statistics } \\
\hline $\mathbf{n}$ & I agree & Percent & $\begin{array}{c}\text { Partially } \\
\text { agree }\end{array}$ & Percent & Disagree & Pecent & Mean & $\begin{array}{c}\text { Std. } \\
\text { Deviation }\end{array}$ \\
\hline $\mathrm{n}_{3}$ & 50 & 80.6 & 10 & 16.1 & 2 & 3.2 & 1.23 & .493 \\
\hline $\mathrm{n}_{4}$ & 38 & 61.3 & 31 & 33.9 & 3 & 4.8 & 1.44 & .590 \\
\hline $\mathrm{n}_{5}$ & 60 & 96.8 & 1 & 1.6 & 1 & 1.6 & 1.05 & .282 \\
\hline $\mathrm{n}_{6}$ & 58 & 93.5 & 3 & 4.8 & 1 & 1.7 & 1.08 & .329 \\
\hline $\mathrm{n}_{7}$ & 24 & 38.7 & 20 & 32.3 & 18 & 29 & 1.90 & .824 \\
\hline $\mathrm{n}_{8}$ & 44 & 71.0 & 14 & 22.6 & 4 & 6.5 & 1.35 & .603 \\
\hline $\mathrm{n}_{9}$ & 40 & 64.5 & 17 & 27.4 & 5 & 8.1 & 1.44 & .643 \\
\hline $\mathrm{n}_{10}$ & 46 & 74.2 & 16 & 25.8 & 0 & 0.0 & 1.26 & .441 \\
\hline $\mathrm{n}_{11}$ & 44 & 71 & 15 & 24.2 & 3 & 4.8 & 1.34 & .571 \\
\hline $\mathrm{n}_{12}$ & 32 & 51.6 & 23 & 37.1 & 7 & 11.3 & 1.60 & .689 \\
\hline $\mathrm{n}_{13}$ & 46 & 74.2 & 14 & 22.6 & 2 & 3.2 & 1.29 & .524 \\
\hline
\end{tabular}

Source: Author research

After statistically presenting the answers given in Table 4, it can be concluded that the majority of respondents agree with the question asked. The highest average values have the answers to the questions in which the respondents completely agree, in questions $\mathrm{n}_{5}$, $\mathrm{n}_{6}, \mathrm{n}_{3}, \mathrm{n}_{10}$ and $\mathrm{n}_{13}$, while the lowest average values in the answers of the agreement with the statement, recorded in questions $n_{7}, n_{12}$ and $n_{4}$. An insight into the data in Table 4 reveals statistically significant differences in the outputs. These statistically significant differences can be examined with the help of Analysis The Pearson Correlations, which determines whether the model of statistically significant differences obtained is relevant for reaching conclusions, the respondents 'attitudes have a significant role in creating the research conclusions, and to what extent the respondents' attitudes may influence to draw conclusions about the impact of complementary medicine on sustainable tourism development, through spa, events and nature-based tourism, as shown in Table 5. 
Table 5. Analysis The Pearson Correlations

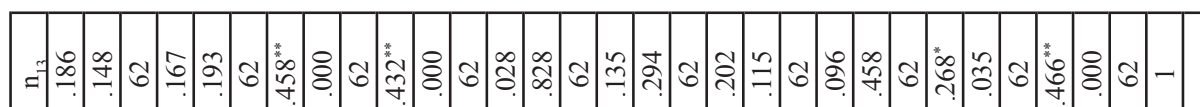

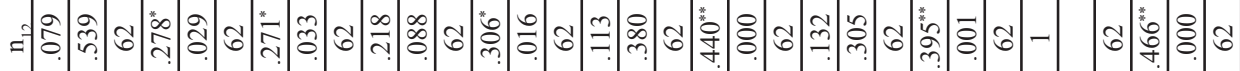

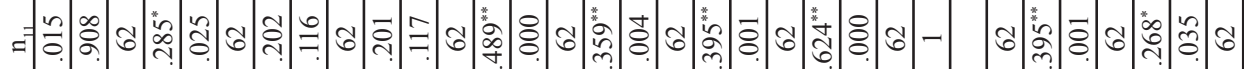

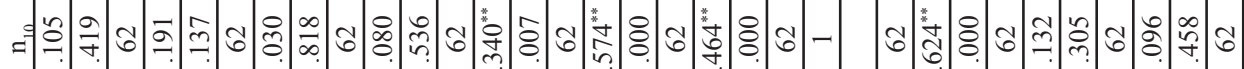

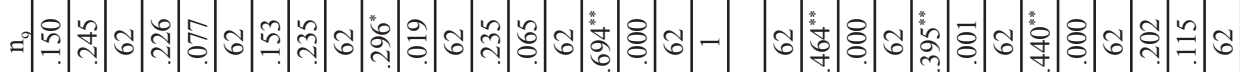

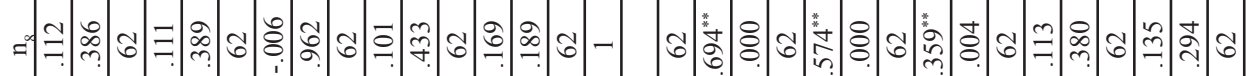

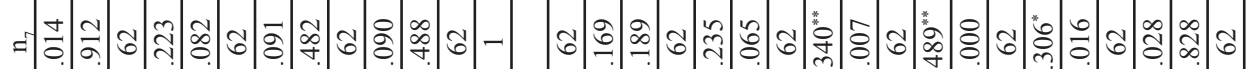

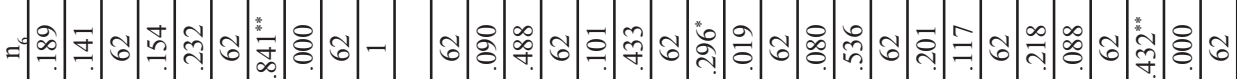

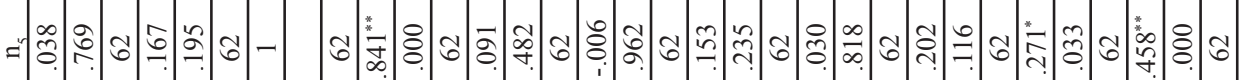

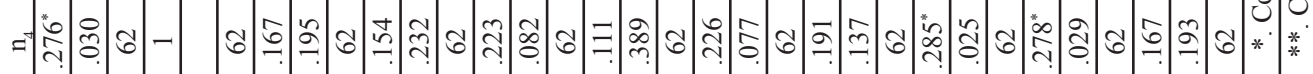

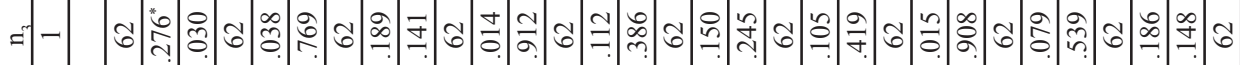

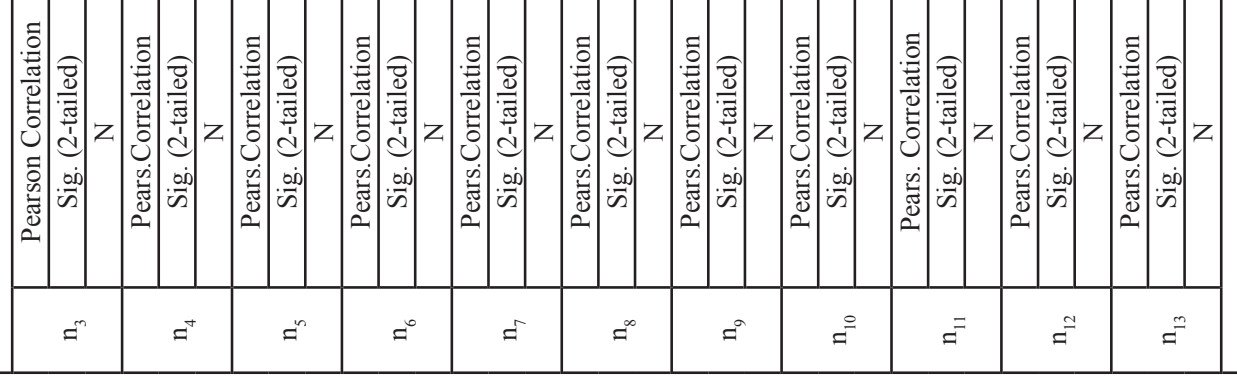

Source: Author research 
The correlation results indicate that the respondents tend to express the differences in the answers, which to a greater extent confirm certain claims. This result indicates that a significant number of respondents agree with the claim that complementary medicine has a significant share in the creation of the tourist offer of the destination. The smaller number of respondents, from the largest clusters of Serbia and abroad, can represent a significant sample for analyzing the impact of complementary medicine on sustainable tourism development through events, spa and nature-based tourism. The results obtained may be significant for the comparative analysis of sustainable tourism development in the Republic of Serbia. It can be concluded that understanding of the importance of the implementation of complementary medicine in the tourist offer of Serbia is present, especially through the organization of special events, because through events, spa and nature-based tourism, such sustainable tourism development provides different benefits (Traskevich \& Fontanari, 2018; Trišić et al., 2020). This refers to data indicating that only a small number of respondents disagree with the statements made in the questions asked. What is significant is that there is an intense increase in awareness among the respondents about the importance of complementary medicine in tourism planning and development, precisely through events and nature-based tourism. The results obtained in this way can be of great importance in domestic and foreign tourism. Tourists from the countries of the region, such as Bosnia and Herzegovina, Croatia, Hungary, Romania, Bulgaria, as well as other European and world countries, are increasingly visiting the Republic of Serbia. Much of the tourism demands are directed specifically to events, spa and nature-based tourism. By developing such forms of tourism, it strengthens tourists' awareness of the importance of nature and environment, as an indispensable factor in tourism development (Valdivieso, Eagles \& Gil, 2015; Geneletti, Scolozzi \& Esmail, 2018).

\section{Conclusions}

The conducted research has enabled the constitution of scientific knowledge that tourists are very happy to opt for activities of traditional medicinal herbs collection, significant in complementary medicine. Such activities are realized in nature, with which tourists came in direct contact (Bottero et al., 2019). Using these resources can encourage their renewal and improvement, which is a segment of sustainable tourism development (Schmudde, 2015; Bello, Carr \& Lovelock, 2016). Herbs collection activities would form a positive collective socio-cultural impact, both on tourists and on the local community (Page et al., 2017; Đurađević \& Dimitrovski, 2019). The local community plays an important role in promoting these natural values of the tourist destination. Respondents, through their questionnaire, just gave importance to events, wellness and spa forms of tourism (Đurađević, 2017), which, with the aforementioned nature-based motives, can enhance Vrnjačka Banja's importance in terms of competing tourist destinations. The research and analysis of the obtained results confirmed two sets of scientific hypotheses. These are that complementary medicine is a significant component of the sustainable development of health tourism in Serbian spa destinations and that organizing an adequate complementary medicine tourism event can increase tourists' motivation for visits and their significant relationship to nature-based tourism 
(through traditional plant picking and stay in nature), which would have a significant impact on the sustainable tourism development of spa tourism. Also, the results of the research in this paper showed that complementary medicine is a significant component of the development of health tourism in Serbia, and that the organization of adequate tourist events in the field of complementary medicine would increase the motivation of tourists to visit, which would significantly improve the overall sustainable tourism development of tourism. industry. The results obtained may also be significant for a comparative analysis of sustainable tourism development in the Republic of Serbia. It can be concluded that there is an understanding of the importance of implementing complementary medicine in the tourist offer of Serbia, because through events, spa and nature-based tourism, such sustainable tourism development provides different benefits. The concluding remarks made can be of great importance in domestic and international tourism. Tourists from the countries of the region, such as Bosnia and Herzegovina, Croatia, Hungary, Romania, Bulgaria, as well as other European and world countries, are increasingly visiting the Republic of Serbia. Respondents, although the number of them is not so large, represent a significant sample for correlating and comparing tourism development at local, national and regional levels. Much of the world's tourism demand is directed specifically to events, spa and nature-based tourism (Koskinen \& Wilska, 2019). Complementary medicine can represent a significant link between these three important forms of tourism for Serbia, and by providing socio-cultural, economic and environmental benefits, the basic postulates of sustainable tourism development are directly fulfilled.

\section{Conflict of interests}

The authors declare no conflict of interest.

\section{References}

1. Aldebert, B., Dang, R. \& Longhi, C. (2011). Innovation in the tourism industry: the case of tourism@. Tourism Management, 32(5), 1204-1213, https://doi. org/10.1016/j.tourman.2010.08.010

2. Bello, F.G., Carr, N., \& Lovelock, B. (2016). Community participation framework for protected area-based tourism planning. Tourism Planning \& Development, 13(4), 469-485. doi:10.1080/21568316.2015.1136838

3. Bottero, M., Comino, E., Dell'Anna, F., Dominici, L., \& Rosso, M. (2019). Strategic assessment and economic evaluation: the case study of Yanzhou Island (China). Sustainability, 11(4), 1076. https://doi.org/10.3390/su11041076

4. Connell, J. (2013). Contemporary medical tourism: Conceptualisation, culture and commodification. Tourism Management, 34, 1-13. https://doi.org/10.1016/j. tourman.2012.05.009 
5. Cvijanović, D., Pantić, N., \& Ignjatijević, S. (2019). Economic analysis of employment and GDP in EU countries. Ekonomija: teorija i praksa, 12(4), 11-23. https://doi.org/10.5937/etp1904011C

6. Cvijanović, D., Simić, N., \& Vukotić, S. (2018). Creating a state brand: A brand and branding Serbia. Ekonomika, 64(2), 43-54. https://doi.org/10.5937/ ekonomika1802043C

7. Dimitrovski, D., \& Todorović, A. (2015). Clustering wellness tourists in spa environment. Tourism Management Perspectives, 16, 259-265, https://doi. org/10.1016/j.tmp.2015.09.004

8. Doran, R., Hanss, D., \& Larsen, S. (2017). Intentions to make sustainable tourism choices: do value orientations, time perspective, and efficacy beliefs explain individual differences? Scandinavian Journal of Hospitality and Tourism, 17(3), 223-238. doi:10.1080/15022250.2016.1179129

9. Dryglas, D. (2009). Product innovations in spa tourism. In: Association of Spa Municipalities RP (Ed.), Innovative development directions spa tourism and spa treatment (pp. 167-174). Krynica.

10. Đurađević, M. (2017). Karakteristike korisnika usluga wellness turizma Specijalne bolnice „Merkur"[in English: Characteristics of wellness tourism users in “Merkur” Specialised Hospital]. Hotel and Tourism Management, 5(1), 75-84.

11. Đurađević, M., \& Dimitrovski, D. (2019). Quality analysis of event "Veseli Spust": A consumer perspective. Marketing, 50(2), 135-142. https://doi.org/10.5937/ markt1902135Q

12. Event Management Body of Knowledge (1999), Retrieved from www.embok.org (January 13, 2019).

13. Geneletti, D., Scolozzi, R., \& Esmail, B.A. (2018). Assessing ecosystem services and biodiversity tradeoffs across agricultural landscapes in a mountain region. International Journal of Biodiversity Science, Ecosystem Services \& Management, 14(1), 188-208. doi:10.1080/21513732.2018.1526214

14. Getz, D. \& Page, S. (2016). Progress and prospects for event tourism research. Tourism Management, 52, 593-631, https://doi.org/10.1016/j.tourman.2015.03.007

15. Giampiccoli, A., Lee, S., \& Nauright, J. (2015). Destination South Africa: Comparing global sports mega-events and recurring localised sports events in South Africa for tourism and economic development. Current Issues in Tourism, 18(3), 229-248, https://doi.org/10.1080/13683500.2013.787050

16. Golob, A., Lesjak, M., Fabjan, D., Jakulin, T., \& Stamenković, I. (2015). Assessment of sustainability of sports events (Slovenia). Turizam, 19(2), 71-83, https://doi.org/10.5937/Turizam1502071G 
17. Hadzik, A. (2009). Wellness tourism as an example of an innovative direction in spas. theory and practice. In: Association of Health Resorts of the Republic of Poland (Ed.). Innovative directions for the development of spa tourism and spa treatment (pp. 199-221). Krynica.

18. Health and wellness tourism in Poland. (2015). Report. Euromonitor International.

19. Joshi, A., Kale, S., Chandel, S., \& Pal, D.K. (2015). Likert scale: explored and explained. British Journal of Applied Science \& Technology, 7(4), 396-403. doi:10.9734/BJAST/2015/14975

20. Kim, M., Lee, C.K., Kim, J.S., Petrick, J.F. (2019). Wellness pursuit and slow life seeking behaviors: moderating role of festival attachment. Sustainability, 11(7), 2020. https://doi.org/10.3390/su11072020

21. Koskinen, V., \& Wilska, T.A. (2019). Identifying and understanding spa tourists' wellness attitudes. Scandinavian Journal of Hospitality and Tourism, 19(3), 259277. https://doi.org/10.1080/15022250.2018.1467276

22. Kostić, M., Ratković, M., \& Forlani, F. (2019). Eco-hotels as an example of environmental responsibility and innovation in savings in the hotel industry. Hotel and Tourism Management, 7(2), 47-56. https://doi.org/10.5937/ menhottur1902047K

23. Manić, M. (2018). Marketing approach to specific forms of tourism in the context of revitalization of undeveloped areas in eastern Serbia. Marketing, 49(4), 299310, https://doi.org/10.5937/markt1804299M

24. Page, S.J., Hartwell, H., Johns, N., Fyall, A., Ladkin, A., \& Hemingway, A. (2017). Case study: Wellness, tourism and small business development in a UK coastal resort: Public engagement in practice. Tourism Management, 60, 466-477. https:// doi.org/10.1016/j.tourman.2016.12.014

25. Pan, X., Yang, Z., Han, F., Lu, Y., \& Liu, Q. (2019). Evaluating potential areas for mountain wellness tourism: a case study of Ili, Xinjiang Province. Sustainability, 11(20), 5668. https://doi.org/10.3390/su11205668

26. Sallmann, N. (Ed.). (2010). Megatrend wellness \& spa for the leisure and hotel services market in the $21^{\text {st }}$ century. Krakow: Pag.

27. Sawicki, Z. (2014). New trends of spa and wellness tourism in the Allgau Alps region. In: J. Marak, J. Wyrzykowski, \& M. Szymczyk, (Eds.), Health, wellness \& spa tourism as the regional product - theory and practice (pp. 241-252). Wroclaw: University of Business in Wrocław, University of Business in.

28. Schmudde, R. (2015). Equestrian tourism in national parks and protected areas in Iceland-an analysis of the environmental and social impacts. Scandinavian Journal of Hospitality and Tourism, 15(1-2), 91-104._doi:10.1080/15022250.201 $\underline{4.1000713}$ 
29. Senić, R. \& Senić, V. (2016). Marketing menadžment u turizmu. Vrnjačka Banja: Fakultet za hotelijerstvo i turizam [in English: Senić, R. and Senić, V. (2016), Marketing management in tourism, Faculty of Hotel Management and Tourism Vrnjačka Banja].

30. Smith, M., \& Puczkó, L. (2015). More than a special interest: defining and determining the demand for health tourism. Tourism Recreation Research, 40(2), 205-219. https://doi.org/10.1080/02508281.2015.1045364

31. Suess, C., Baloglu, S., \& Busser, J.A. (2018). Perceived impacts of medical tourism development on community wellbeing. Tourism Management, 69, 232245. https://doi.org/10.1016/j.tourman.2018.06.006

32. The Global Wellness Tourism Economy 2013-2014. (2015). Report final. Global Wellness Institute.

33. Traskevich, A., \& Fontanari, M. (2018). Mental wellness in resilient destinations. International Journal of Spa and Wellness, 1(3), 193-217. https://doi.org/10.1080 $\underline{124721735.2019 .1596656}$

34. Trišić, I., Štetić, S., \& Krstić, V. (2018). Possibilities to prevent negative environmental impacts. Economic of Agriculture, 65(4), 1599-1614. doi:10.5937/ ekoPolj1804599T

35. Trišić, I., Štetić, S., Privitera, D., \& Nedelcu, A. (2020). Wine routes in Vojvodina Province, Northern Serbia - a tool for sustainable tourism development. Sustainability, 12(1), 82. https://doi.org/10.3390/su12010082

36. Tucki, A., \& Hadzik, A. (2013). Analysis of opportunities for the development of health tourism in the Lublin province in the context of the region's identified smart specialization in the field of medical services and healthy. Lublin: Marshal's Office of the Lublin Voivodeship.

37. Valdivieso, J.C., Eagles, P.F.J., \& Gil, J.C. (2015). Efficient management capacity evaluation of tourism in protected areas. Journal of Environmental Planning \& Management, 58(9), 1544-1561. doi:10.1080/09640568.2014.937479

38. Vetitnev, A.M., \& Kuskov, A.S. (2010). Medical tourism. Moscow: Forum.

39. Vujović, S., Cvijanović, D., \& Štetić, S. (2012). Destinacijski koncept razvoja turizma. Beograd: Institut za ekonomiku poljoprivrede [in English: Vujović, S., Cvijanović, D., \& Štetić, S. (2012), Destination concept of tourism development, Institute of Agricultural Economics, Belgrade].

40. Vujović, S., Ćurčić, N., \& Miletić, V. (2016). Impact of tourism on roundabout of economic process. Economic of Agriculture, 63(1), 323-337. https://doi. org/10.5937/ekoPolj1601323V

41. Wardle, C., Buckley, R., Shakeela, A., \& Castley, J.G. (2018). Ecotourism's contributions to conservation: analysing patterns in published studies. Journal of Ecotourism. doi:10.1080/14724049.2018.1424173 
42. Whittle, P.M., Stewart, E.J., \& Fisher, D. (2015). Re-creation tourism: de-extinction and its implications for nature-based recreation. Current Issues in Tourism, 18(10), 908-912. doi:10.1080/13683500.2015.1031727

43. Wisnom, M., \& Gallagher, K. (2018). Quality of work life in the resort spa industry. International Journal of Spa and Wellness, 1(3), 159-177. https://doi.o $\mathrm{rg} / 10.1080 / 24721735.2019 .1596658$

44. Yoo, I.Y., Lee, T.J., \& Lee, C.K. (2015). Effect of health and wellness values on festival visit motivation. Asia Pacific Journal of Tourism Research, 20(2), 152170. https://doi.org/10.1080/10941665.2013.866970

45. Živković, R. (2009). Ponašanje i zaštita potrošača u turizmu. Beograd: Univerzitet Singidunum [in English: Živković, R. (2009), Consumer behavior and protection in tourism, University of Singidunum, Belgrade]. 